\title{
太陽光励起レーザー用Ce/Cr/Nd:YAG材料の蛍光特性評価
}

\author{
藤岡 加奈 ${ }^{1}$, 中塚 正大 $^{1}$, 佐伯 拓 ${ }^{2}$, 本越 伸二 $^{2}$, 今崎一夫 ${ }^{2}$, 藤本 靖 $^{1}$, 藤田 尚德 $^{1}$ \\ '大阪大学レーザーエネルギー学研究センター（テ565-0871 大阪府吹田市山田丘2-6) \\ ${ }^{2}$ レーザー技術総合研究所 ( $5500-0004$ 大阪府大阪市北区勒町 1-8-4)
}

\section{Luminescence Properties of Ce/Cr/Nd:YAG Materials for Solar-Pumped Lasers}

\author{
Kana FUJIOKA, ${ }^{1}$ Masahiro NAKATSUKA, ${ }^{1}$ Taku SAIKI, ${ }^{2}$ Shinji MOTOKOSHI, ${ }^{2}$ Kazuo IMASAKI, ${ }^{2}$ \\ Yasushi FUJIMOTO, ${ }^{1}$ and Hisanori FUJITA ${ }^{1}$ \\ ${ }^{1}$ Institute of Laser Engineering, Osaka University, 2-6 Yamadaoka, Suita, Osaka 565-0871 \\ ${ }^{2}$ Institute for Laser Technology, 1-8-4 Utubohonnmachi, Nishi-ku, Osaka, Osaka 550-0004
}

(Received November 2, 2009)

\begin{abstract}
$\mathrm{Cr}^{3+}$ additive is commonly applied for flash-lamp or solar-pumped laser systems to enhance the overall laser efficiency of Nd:YAG. We examined the effectiveness of new elements on the further excitation efficiency enhancement of $\mathrm{Cr} / \mathrm{Nd}$ :YAG. Such elements as $\mathrm{Ti}^{3+}, \mathrm{Co}^{2+}, \mathrm{Ce}^{3+}, \mathrm{Eu}^{3+}, \mathrm{Pr}^{3+}$, and $\mathrm{V}^{3+}$ were doped into YAG ceramic powders synthesized by a sol-gel method, because these absorptions exist between 300 and $500 \mathrm{~nm}$. The experimental results verified that $\mathrm{Ce}^{3+}$ was the most effective element. The most effective $\mathrm{Ce}^{3+}$ concentration to $0.3 \mathrm{~mol} \%-\mathrm{Cr} / 1.0 \mathrm{~mol} \%$-Nd:YAG ceramic powder was $0.9 \mathrm{~mol} \%$ and the excitation efficiency was enhanced to 2.4 times more than that of $\mathrm{Cr} / \mathrm{Nd}$ :YAG without $\mathrm{Ce}^{3+}$. The energy transfer of $\mathrm{Ce}^{3+} \rightarrow \mathrm{Nd}^{3+}$ probably occurred because the effective lifetime of $\mathrm{Nd}^{3+}$ ion in $\mathrm{Ce} / \mathrm{Cr} / \mathrm{Nd}$ :YAG almost equaled the lifetime of $\mathrm{Nd}^{3+}$ ion in $\mathrm{Nd}$ :YAG. $\mathrm{Ce} / \mathrm{Cr} / \mathrm{Nd}$ : $\mathrm{YAG}$ might be a new laser material for solar and flash-lamp pumped lasers.
\end{abstract}

Key Words: Ce/Cr/Nd:YAG, Cr/Nd:YAG, Sol-gel, Multi-dope, Ceramics

\section{1. はじめに}

太陽光やフラッシュランプによるNd:YAGの励起効率 を上げるため, 増感剤として $\mathrm{Cr}^{3+}$ が用いられている $\mathrm{Cr}^{3+}$ は紫外から可視域にかけてブロードで強い吸収を持 ち, 太陽光やフラッシュランプ光を吸収し，そのエネル ギーを効率よく $\mathrm{Nd}^{3+} に$ 移譲することが出来る. $\mathrm{Cr}^{3+}$ を ドープした高品質なYAG単結晶は作製が困難であるが, セラミック化することでレーザー材料グレードの Cr/ $\mathrm{Nd}$ : YAGが得られるようになり, 太陽光励起レーザーをは じめとする紫外・可視光励起レーザーの分野での研究が 進んでいる ${ }^{7-20)}$ 。我々は，更に励起効率を上げるため， 太陽光スペクトルのうち $\mathrm{Cr} / \mathrm{Nd}: \mathrm{YAG}$ の励起に未だ利用さ れていない紫外・可視域(特に300〜 $500 \mathrm{~nm}$ ) に着目し, この波長域に吸収を持ち, かつ $\mathrm{Nd}^{3+}$ エネルギー移譲が 可能な元素を共添加したセラミックYAGの開発を進め ている，共添加する元素に望まれる条件は以下の通りで ある. (1)YAGに添加可能であること. (元素の価数, 配 位数, イオン半径などで決まる), (2)紫外光により励起 され(紫外波長域に吸収を持つ), $\mathrm{Nd}: \mathrm{YAG}$ の励起スペク

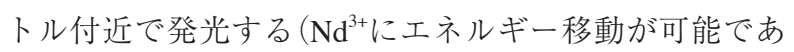
る)，(3) $\mathrm{Nd}^{3+}$ の発光波長である $1 \mu \mathrm{m}$ 付近に吸収がないこ
と，(4)人，環境に無害であること。我々はこの4つの条 件を満たす元素の候補として $\mathrm{Ti}^{3+}, \mathrm{Co}^{2+}, \mathrm{Ce}^{3+}, \mathrm{Eu}^{3+}$, $\mathrm{Pr}^{3+}, \mathrm{V}^{3+}$ を選択した。

この論文では, $\mathrm{Ti}^{3+}, \mathrm{Co}^{2+}, \mathrm{Ce}^{3+}, \mathrm{Eu}^{3+}, \mathrm{Pr}^{3+}, \mathrm{V}^{3+}$ ドープしたYAGセラミック粉体をsol-gel法で製作し評価 を行った。そその結果, $\mathrm{Ce}^{3+}$ が $\mathrm{Cr} / \mathrm{Nd}$ : YAG中の $\mathrm{Nd}^{3+}$ の増感 剤として有効であることを明らかにした。更に，異なる $\mathrm{Ce}^{3+}$ 添加量の $\mathrm{Ce} / \mathrm{Cr} / \mathrm{Nd}: \mathrm{YAG}$ セミミック粉体の蛍光スペク トル, 蛍光強度, 蛍光寿命の $\mathrm{Ce}^{3+}$ イオン添加濃度依存性 を評価し, $\mathrm{Ce}^{3+}$ イオンの共添加により $1064 \mathrm{~nm}$ での発光 の励起効率が $\mathrm{Ce}^{3+}$ を添加しない場合の2.4倍に増加するこ とが明らかになったので報告する。

\section{2. 実 験}

\subsection{YAGセラミック粉体の製作}

測定用粉体はsol-gel法で製作した ${ }^{21,22)}$ 。粉体の分光特 性により，バルク体のそれを評価できることはref. $22 に$ 示してある。試薬は97\% $\mathrm{Al}\left(\mathrm{O}-\mathrm{sec}-\mathrm{C}_{4} \mathrm{H}_{9}\right)_{3}, 99.99 \% \mathrm{Y}$ $\left(\mathrm{CH}_{3} \mathrm{COO}\right)_{3} \cdot 4 \mathrm{H}_{2} \mathrm{O}, \mathrm{Cr}\left(\mathrm{CH}_{3} \mathrm{COO}\right)_{3} \cdot x \mathrm{H}_{2} \mathrm{O}, \mathrm{Nd}$ $\left(\mathrm{CH}_{3} \mathrm{COO}\right)_{3} \cdot x \mathrm{H}_{2} \mathrm{O}$, 無水2-プロパノール(含水量 $0.005 \% \mathrm{max}$ )を使用した。水は抵抗值 $12.6 \mathrm{M} \Omega$ 以上の超 
純水を用いた。添加する元素 $\mathrm{Ti}^{3+}, \mathrm{Co}^{2+}, \mathrm{Ce}^{3+}, \mathrm{Eu}^{3+}$, $\mathrm{Pr}^{3+}, \mathrm{V}^{3+}$ の試薬, 濃度などの詳細はTable 1に示した。い ずれの添加元素も $\mathrm{Y}\left(\mathrm{CH}_{3} \mathrm{COO}\right)_{3}$ 水溶液に溶解した. $\mathrm{Co}^{2+}$ は価数制御が必要あるため, $\mathrm{Zr}^{4+}$ を添加した。試薬は $15.5 \% \mathrm{Zr}\left(\mathrm{CH}_{3} \mathrm{COO}\right)_{4}$ 酢酸溶液を用いた。 $\mathrm{Y}^{3+}$ イオンのサ イトに置換される元素をドープする場合は, 添加する元 素と同モル濃度の $\mathrm{Y}^{3+}$ を減じ, $\mathrm{Al}^{3+}$ イオンのサイトに置換 される元素をドープする場合は, 添加する元素と同モル 濃度の $\mathrm{Al}^{3+}$ を減じた。濃度mol\%はYAG中のそれぞれ $\mathrm{Y}^{3+}$, $\mathrm{Al}^{3+}$ 対する割合を示す。

製作した粉末のX線回折測定を行い，いずれの粉体も ICDDカードのYAGのピークと非常に良く一致し，YAP $\left(\mathrm{YAlO}_{3}\right), \quad \mathrm{YAM}\left(\mathrm{Y}_{4} \mathrm{Al}_{2} \mathrm{O}_{9}\right)$ などの他相の析出がないこと が確認できた ${ }^{23)}$ 。また, 組成はICP発光分析で確認し た。

\section{2 測定方法}

吸収スペクトルの測定は分光光度計U-4100 (HITACHI) を用い，反射法で行った。 スキャン範囲は300〜 $1300 \mathrm{~nm}$, スキャン速度は300 nm/min, スリット幅は $700 \mathrm{~nm}$ では $1.0 \mathrm{~nm}$, それより長波長領域は自動調節 モードで測定した。

蛍光スペクトル，励起スペクトル，蛍光寿命の測定 は, 日本分光高分解能蛍光分光装置SS-25を用いた。測 定間隔は $1 \mathrm{~nm}$ ，スキャン速度は $200 \mathrm{~nm} / \mathrm{min}$ で測定した。

また, Ce:YAG中のCe $\mathrm{Ce}^{3+}$ イオンの蛍光寿命測定は, $\mathrm{Ce}^{3+}$ イオンの蛍光寿命がnsecオーダーで非常に短いため,

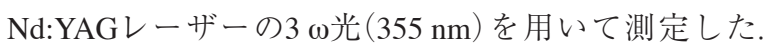
レーザーの出力は $250 \mathrm{~mW}$, 繰返し速度は $10 \mathrm{~Hz}$ ，パルス 幅は3 nsec，レーザーのパルス幅が有限值であることは 補正されている。検知器に, InGaAsのピンダイオード を用いて, $530 \mathrm{~nm} て ゙ の$ 発光の減衰過程をオシロスコー プで観測した。

測定用サンプルとして, セラミック粉体 $0.5 \mathrm{~g}$ を $1.0 \mathrm{w} \%$ ポリビニルアルコール水溶液 $1 \mathrm{ml}$ に均一に懸濁 し, その溶液 $0.2 \mathrm{ml}$ をライドガラスのスリの部分に塗 布し乾燥させたものを製作した。

\section{3. 結果と考察}

\section{1 添加元素の選定}

YAGは単位格子が8個含まれる立方晶系単位格子を持 つガーネット構造で，Fig. 1に示すように酸素で囲まれ た十二面体8配位の $\mathrm{Y}^{3+}$ イオン，四面体4配位の $\mathrm{Al}^{3+}$ イオ ン，八面体6配位の $\mathrm{Al}^{3+}$ イオンで構成されている。 $\mathrm{Y}^{3+}$ イ オンのイオン半径は $0.900 \AA$ ，4配位の $\mathrm{Al}^{3+}$ イオン，6配位 の $\mathrm{Al}^{3+}$ イオンはそれぞれ $0.39 \AA ， 0.535 \AA$ である ${ }^{24)}$. 添加 する元素 $\mathrm{Ti}^{3+}, \mathrm{Co}^{2+}, \mathrm{Ce}^{3+}, \mathrm{Eu}^{3+}, \mathrm{Pr}^{3+}, \mathrm{V}^{3+}$ のイオン半 径, 配位数 (Table 1) を考慮すると, $\mathrm{Ce}^{3+}, \mathrm{Eu}^{3+}, \mathrm{Pr}^{3+}$ は $\mathrm{Y}^{3+}$ イオンのサイト, $\mathrm{Ti}^{3+}, \mathrm{V}^{3+}$ は6配位の $\mathrm{Al}^{3+}$ イオンのサ イト, $\mathrm{Co}^{2+}$ は4配位の $\mathrm{Al}^{3+}$ イオンのサイトに入ると考えら れる。それぞれの元素をYAGに添加した粉体サンプル の吸収スペクトル測定結果をFig. 2に示す。ベースライ ン較正は同様に作製したno-doped YAG粉体を用いた。 $\mathrm{Co}^{2+}$ は1064 nm付近に吸収が認められ，目的に不適当で あると判断した。他の5元素 $\mathrm{Ti}^{3+}, \mathrm{Ce}^{3+}, \mathrm{Eu}^{3+}, \mathrm{Pr}^{3+}, \mathrm{V}^{3+}$ は1064 nm付近に吸収がなく，紫外・可視領域に吸収が あった。吸収が観察された波長は, $\mathrm{Eu}^{3+}$ は350 nm〜 $400 \mathrm{~nm}, \quad \operatorname{Pr}^{3+}$ は $430 \mathrm{~nm} \sim 500 \mathrm{~nm}$ と $570 \mathrm{~nm} \sim 620 \mathrm{~nm}, \mathrm{Ti}^{3+}$

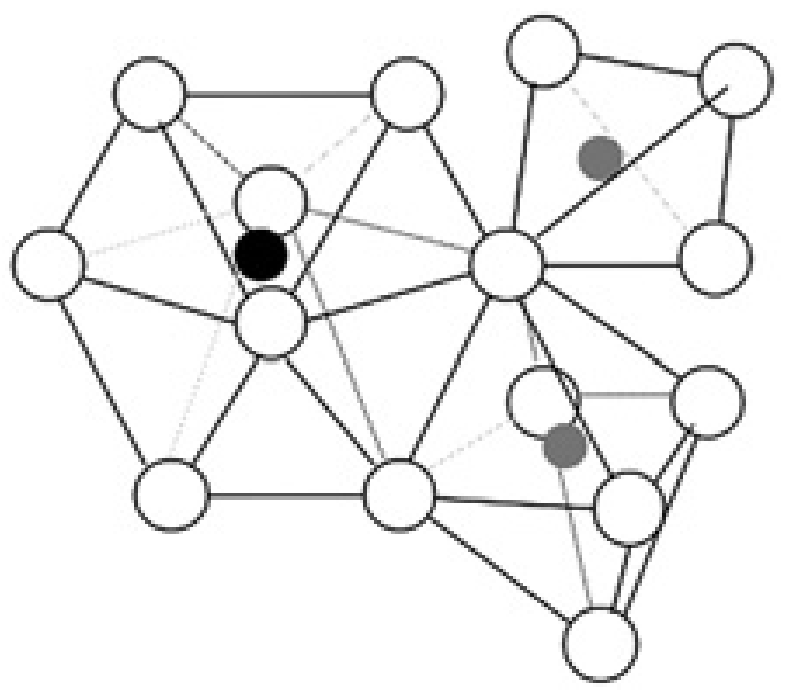

Fig. 1 Unit cell of YAG.

Table 1 Properties of additional element and synthesis condition of doped YAG.

\begin{tabular}{|c|c|c|c|c|c|}
\hline $\begin{array}{l}\text { Additional } \\
\text { element }\end{array}$ & $\begin{array}{l}\text { Ion }{ }^{24)} \\
\text { radius } \\
{[\AA ̊]}\end{array}$ & $\begin{array}{l}\text { Coordination } \\
\text { number }\end{array}$ & $\begin{array}{l}\text { Additive } \\
\text { Amount } \\
{[\mathrm{mol} \%]}\end{array}$ & Reagent & $\begin{array}{l}\text { Sintering } \\
\text { atmosphere }\end{array}$ \\
\hline $\mathrm{V}^{3+}$ & 0.64 & 6 & 3.0 & Vanadium(III) chloride $99.5 \%$ & $\begin{array}{l}\mathrm{Ar} \\
0.2 \mathrm{~atm}\end{array}$ \\
\hline $\mathrm{Ti}^{3+}$ & 0.67 & 6 & 3.0 & Titanium(III) chloride solution $24 \%$ & $\begin{array}{l}\mathrm{Ar}+\mathrm{H}_{2}(9: 1) \\
0.2 \mathrm{~atm}\end{array}$ \\
\hline $\mathrm{Co}^{2+}$ & 0.58 & 4 & 1.0 & Cobalt(II) acetate tetrahydrate $98+\%$ & $\mathrm{O}_{2}$ \\
\hline $\mathrm{Ce}^{3+}$ & 1.01 & 8 & 1.0 & Cerium(III) acetate monohydrate $99.99 \%$ & air \\
\hline $\mathrm{Eu}^{3+}$ & 0.947 & 8 & 3.0 & Europium(III) acetate hydrate $99.9 \%$ & air \\
\hline $\operatorname{Pr}^{3+}$ & 0.997 & 8 & 3.0 & Praseodymium acetate dihydrate $99.9 \%$ & air \\
\hline
\end{tabular}




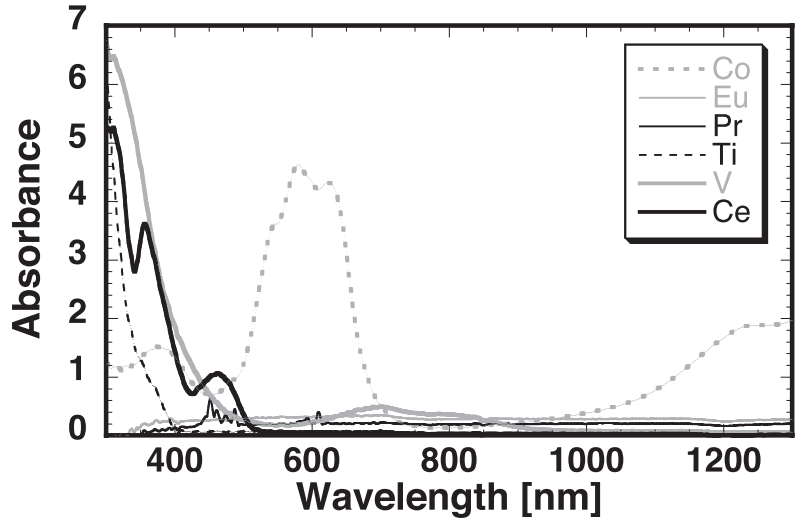

Fig. 2 Absorption spectra of doped YAG powder fabricated by sol-gel technique.

は300 nm〜400 nm， V $\mathrm{V}^{3+}$ は300 nm〜500 nmと600 nm〜 $900 \mathrm{~nm}, \mathrm{Ce}^{3+}$ は $300 \mathrm{~nm} \sim 500 \mathrm{~nm}$ であった。 特に, $\mathrm{Ce}^{3+} に$ 関しては, スペクトル幅広く, 他の元素が $3 \mathrm{~mol} \%$ 添加 されているのに比べ, $1 \mathrm{~mol} \%$ の添加量にも関わらず強 い吸収が観察された。

紫外・可視領域に吸収があったサンプルに関して, 吸 収のあった波長領域の光を励起光として発光の有無を調 べた。 $\mathrm{Ti}^{3+}, \mathrm{V}^{3+}$ は900 nmより短波長領域では発光は観測 されなかった。 $\mathrm{Ce}^{3+}$ は360 nmと460 nm, $\operatorname{Pr}^{3+}$ は300 nmと $454 \mathrm{~nm}, \mathrm{Eu}^{3+}$ は395 nmで励起した時, 紫外・可視領域に

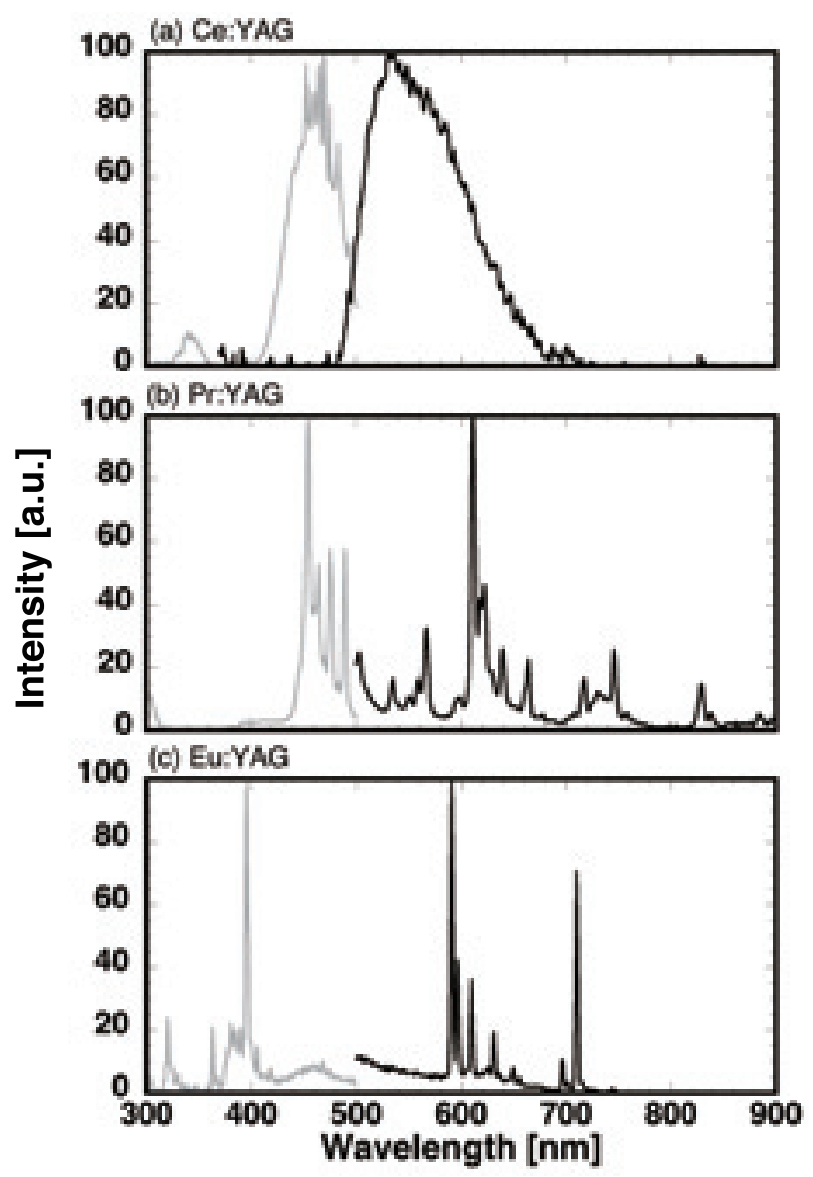

Fig. 3 Emission (black color) and excitation (gray color) spectrum of doped YAG powder fabricated by solgel technique. (a)Ce:YAG powder (b)Pr:YAG powder (c)Eu:YAG powder.
発光が観測された。それぞれのサンプルの励起スペクト ルと発光スペクトルをFig. 3に示す. $\mathrm{Ce}^{3+}$ は5 $44 \mathrm{~nm}$ ピークとするブロードな発光が観測され, $\operatorname{Pr}^{3+}$ は612 nm で， $\mathrm{Eu}^{3+}$ は591 nmと710 nmで発光が観察できた。 発光ス ペクトルのピーク強度を比較するとは, 最も微弱であっ た $\mathrm{Eu}^{3+}$ を基準に1とすると, $\mathrm{Ce}^{3+}$ は非常に高く45倍, $\mathrm{Pr}^{3+}$ は12倍であった。いずれの元素の発光も $\mathrm{Cr} / \mathrm{Nd}: \mathrm{YAG} の$ 励 起スペクトルと重なる部分があるためエネルギー遷移の 可能性はあると思われるが, 吸収のスペクトル幅の広さ と発光強度を考慮し, 増感剤としての有用性が高いのは $\mathrm{Ce}^{3+}$ であると判断した。

\section{$3.2 \mathrm{Ce} / \mathrm{Cr} / \mathrm{Nd}: \mathrm{YAG}$ 蛍光特性の評価}

高品質セラミックを安定供給でき，優れた蛍光特性を 示す $0.3 \mathrm{~mol} \%-\mathrm{Cr} / 1.0 \mathrm{~mol} \%-\mathrm{Nd}: \mathrm{YAG}$ 添加によるスペク トル変化が顕著である $\mathrm{Ce}^{3+}$ 濃度の0.9 mol\%-Ce/0.3 mol\%$\mathrm{Cr} / 1.0$ mol\%-Nd:YAGの1064 nm発光の励起スペクトルを Fig. 4に示した. Cr/Nd:YAGの励起スペクトルはNd:YAG の励起スペクトルに $\mathrm{Cr}^{3+}$ イオンの吸収に由来する380 $500 \mathrm{~nm}\left({ }^{4} \mathrm{~A}_{2} \rightarrow{ }^{4} \mathrm{~T}_{1}\right)$ と $540 \sim 680 \mathrm{~nm}\left({ }^{4} \mathrm{~A}_{2} \rightarrow{ }^{4} \mathrm{~T}_{2}\right)$ の二つのブ ロードなバンドが加わったスペクトル形状である. $\mathrm{Ce}^{3+}$ イオンを添加したことで, $\mathrm{Ce} / \mathrm{Cr} / \mathrm{Nd}: \mathrm{YAG}$ の励起スペク トルは，380〜 500 nmの強度が相対的に増大し，そのバ ンドのピーク波長が4 $40 \mathrm{~nm}$ から $470 \mathrm{~nm}$ に移行した。ま た, $350 \mathrm{~nm}$ 付近のNdによる複数のピークは, 一つのブ ロードな340 nmを中心としたピークになった。これら はCe $\mathrm{C}^{3+}$ イオンの吸収 $\left({ }^{2} \mathrm{~F}_{5 / 2} \rightarrow 5 \mathrm{~d}\right)$ によるものであると思わ れる. $520 \mathrm{~nm}$ り長波長領域のスペクトルは Cr/ $\mathrm{Nd}: \mathrm{YAG}$ の励起スペクトルと一致し変化はなかった。

$470 \mathrm{~nm}$ で励起した $0.9 \mathrm{~mol} \%-\mathrm{Ce} / 0.3 \mathrm{~mol} \%-\mathrm{Cr} / 1.0 \mathrm{~mol} \%$ $\mathrm{Nd}: \mathrm{YAG}$ の発光スペクトルと $808 \mathrm{~nm}$ で励起した $1.0 \mathrm{~mol} \%$ Nd:YAGの発光スペクトルの測定結果をFig. 5に示す。波 長 $850 \mathrm{~nm}$ 以上の発光スペクトルに関しては, $\mathrm{Ce} / \mathrm{Cr} / \mathrm{Nd}$ : YAGとNd:YAGは同一であった。 これらのスペクトル変 化から $\mathrm{Ce}^{3+} \rightarrow \mathrm{Cr}^{3+} \rightarrow \mathrm{Nd}^{3+}$ や $\mathrm{Ce}^{3+} \rightarrow \mathrm{Nd}^{3+}$ のエネルギー遷

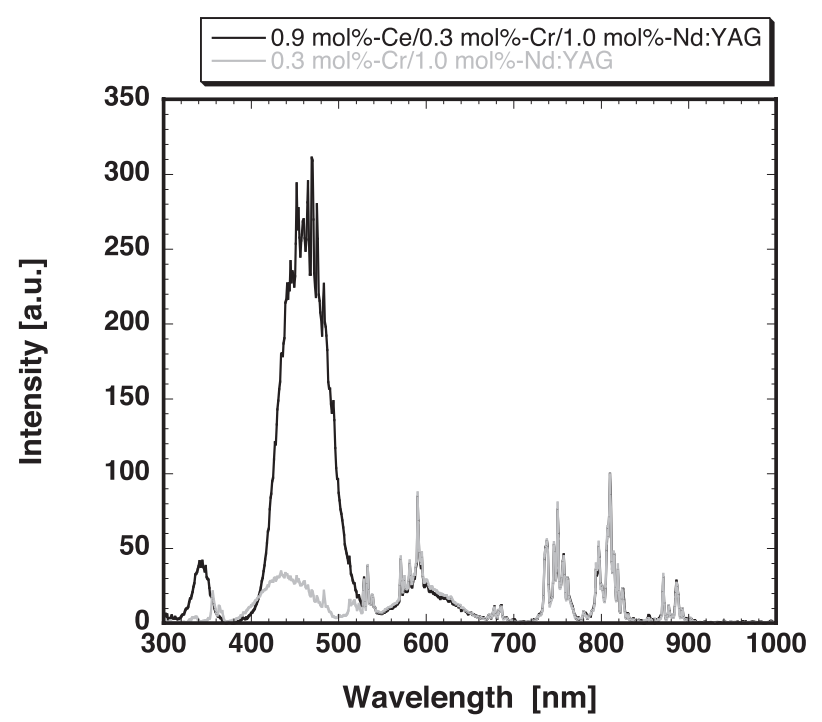

Fig. 4 Excitation spectra of emission at $1064 \mathrm{~nm}$ of $0.9 \mathrm{~mol} \%-\mathrm{Ce} / 0.3 \mathrm{~mol} \%-\mathrm{Cr} / 1.0 \mathrm{~mol} \%-\mathrm{Nd}: \mathrm{YAG}$ and $0.3 \mathrm{~mol} \%-\mathrm{Cr} / 1.0 \mathrm{~mol} \%-\mathrm{Nd}: \mathrm{YAG}$. 


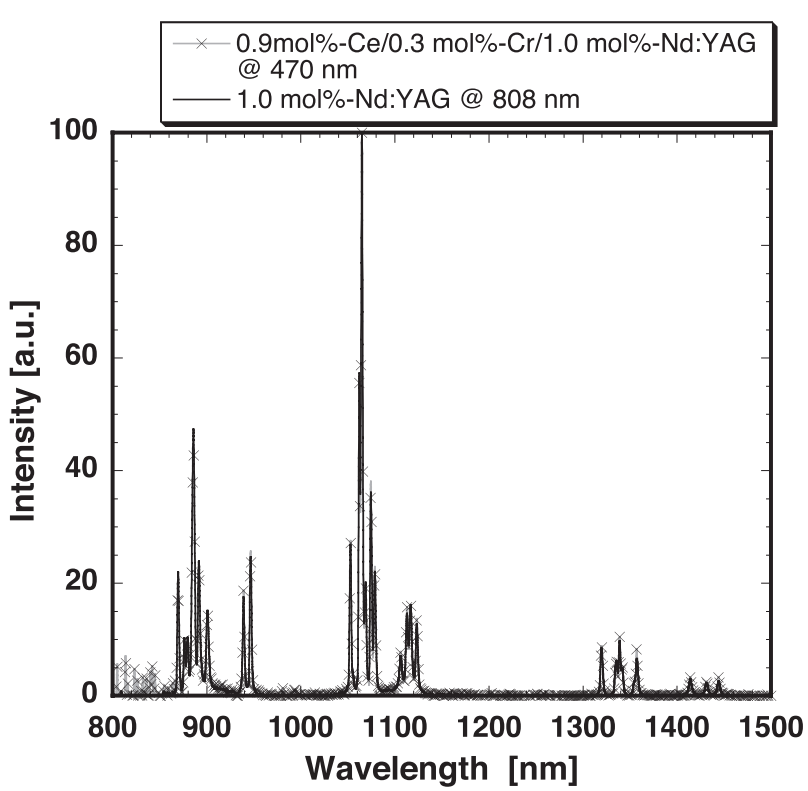

Fig. 5 Fluorescence spectra of $0.9 \mathrm{~mol} \%$-Ce/0.3 mol\%$\mathrm{Cr} / 1.0 \mathrm{~mol} \%$-Nd: YAG excited by $470 \mathrm{~nm}$ and of 1.0mol-Nd: YAG excited by $808 \mathrm{~nm}$.

移が起こっていると予測できる.

\section{$3.3 \mathrm{Ce}^{3+}$ イオン添加濃度の最適化}

0.3 mol\%-Cr/1.0 mol\%-Nd:YAGにCe ${ }^{3+}$ イオンを0.3， 0.6, 0.9，1.2 mol\%をそれぞれ添加したセラミック粉体サン プルの蛍光スペクトル, 励起スペクトル, 蛍光寿命の測 定を行った。各サンプルを波長470 nmで励起した場合 の発光スペクトルをFig. 6に示す。縦軸の強度で絶対值 評価は出来ないが, 各サンプル間の相対評価は可能であ る. $\mathrm{Ce}^{3+}$ 濃度が増加するにつれ，1064 nmにおける発光 強度は増加し， $0.9 \mathrm{~mol} \%$ の場合が最も大きく, $1.2 \mathrm{~mol} \%$ に増加すると逆に減少した， $\mathrm{Ce}^{3+}$ 濃度が $0 \mathrm{~mol} \%$ の場合 (Cr/Nd:YAG) は, 励起波長のピークは440 nmであるた め, $470 \mathrm{~nm}$ 励起では非常に弱い発光しか観測できな かった. $\mathrm{Ce}^{3+}$ 濃度によるスペクトル波形の変化は確認で きなかった。

各サンプルの1064 nm発光の励起スペクトルをFig. 7に 示す. Fig. 6 と同様に縦軸の強度で絶対值評価は出来な いが，各サンプル間の相対評価は可能である. $1064 \mathrm{~nm}$ 発光の励起スペクトルは, $\mathrm{Ce}^{3+}$ 濃度が増加するにつれ, $470 \mathrm{~nm}$ のピーク值が大きくなり, $0.9 \mathrm{~mol} \%$ の場合が最大 で，1.2 mol\%になると逆に減少した。他のピークは大き な変化は無かった。

$\mathrm{Cr}^{3+}$ イオンから $\mathrm{Nd}^{3+}$ イオンへのエネルギー遷移が効率 的に行われることはすでに報告している ${ }^{25)}$ 。第二の増感 剤であるCe $\mathrm{Ce}^{3+}$ イオンを添加した場合のスペクトル変化 は, $\mathrm{Ce}^{3+}$ イオンの基底準位からの ${ }^{2} \mathrm{~F}_{5 / 2} \rightarrow 5 \mathrm{~d}$ のネルギー 遷移に由来するものであると考えられる。 $\mathrm{Ce}^{3+}$ イオン は, Fig. 3 (a) に示すように $340 \mathrm{~nm}$ 光と $470 \mathrm{~nm}$ 光とに よって励起され， $500 \mathrm{~nm}$ から $700 \mathrm{~nm}$ 付近で発光する. $\mathrm{Ce}^{3+}$ イオンの $500 \mathrm{~nm}$ から $700 \mathrm{~nm}$ 付近での発光は $\mathrm{Cr}^{3+}$ イオ ンを励起し, $\mathrm{Cr}^{3+}$ イオンの発光に寄与する。従って, 工 ネルギーがC $\mathrm{e}^{3+}$ イオンから $\mathrm{Cr}^{3+}$ イオンヘ, $\mathrm{Cr}^{3+}$ イオンから

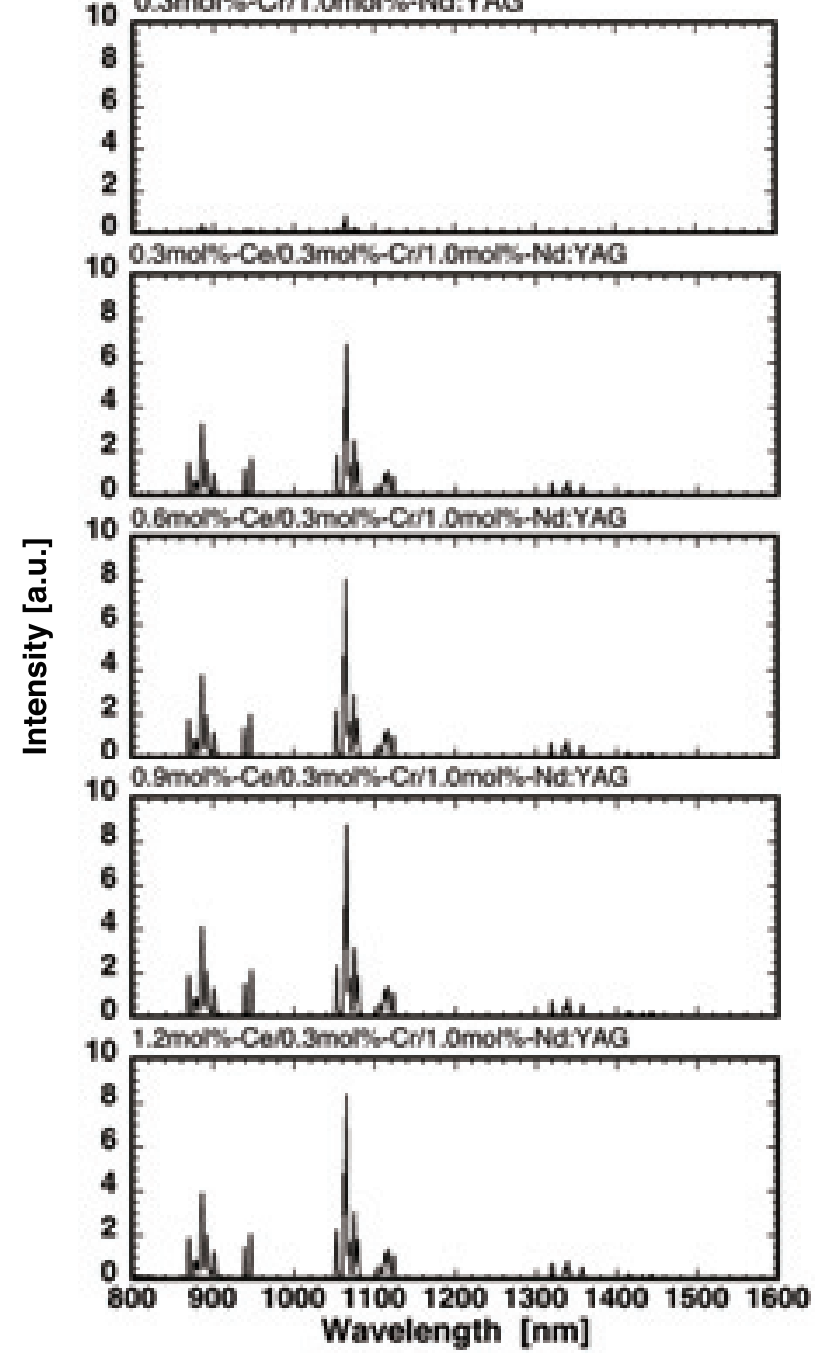

Fig. 6 Fluorescence spectra of excited at $470 \mathrm{~nm}$ of $\mathrm{x}$ $\mathrm{mol} \%-\mathrm{Ce} / 0.3 \mathrm{~mol} \%-\mathrm{Cr} / 1.0 \mathrm{~mol} \%-\mathrm{Nd}$ : YAG. $\mathrm{X}=0$, $0.3,0.6,0.9,1.2$.

へ $\mathrm{Nd}^{3+}$ イオンに遷移がされる。これ以外にも $\mathrm{Ce}^{3+}$ の発光 スペクトルと $\mathrm{Nd}^{3+}$ の励起スペクトルの重なりより, $\mathrm{Ce}^{3+}$ イオンからへ $\mathrm{Nd}^{3+}$ イオンに直接エネルギーが遷移されて いるものもあると考えられる。 この様子をFig. 8 に模式 的に示した

$\mathrm{Ce}^{3+}$ 添加により $\mathrm{Nd}: \mathrm{YAG}$ の励起効率がどの程度上がっ たかの評価は, $1064 \mathrm{~nm}$ 発光に寄与する励起スペクトル の300 nmから $1000 \mathrm{~nm}$ までの面積を比較することにより 可能である。添加したCe $\mathrm{e}^{3+}$ 濃度に対する, Fig. 7の各励 起スペクトルの総面積の変化をFig. 9に示した. $\mathrm{Ce}^{3+}$ 添 加量増加とともに総面積は増加し約 $0.9 \mathrm{~mol} \%$ で最大とな りその後は減少した。 $0.9 \mathrm{~mol} \%$ での総面積は $\mathrm{Ce}^{3+}$ を添加 しなかった場合の2.4倍であった。

複数のイオン間におけるエネルギーの授受は電気双極 子相互作用によって説明される。式(1)はNd/Cr:YAG材 料における $\mathrm{Nd}^{3+}$ と $\mathrm{Cr}^{3+}$ 間のエネルギー授受をそれぞれの 準位間遷移の輻射と吸収の結合係数で表現し，レート方 程式を解くことにより得られる ${ }^{25)}$. 
0.3mol\%-Cr/1.0moko-Nd:YAG

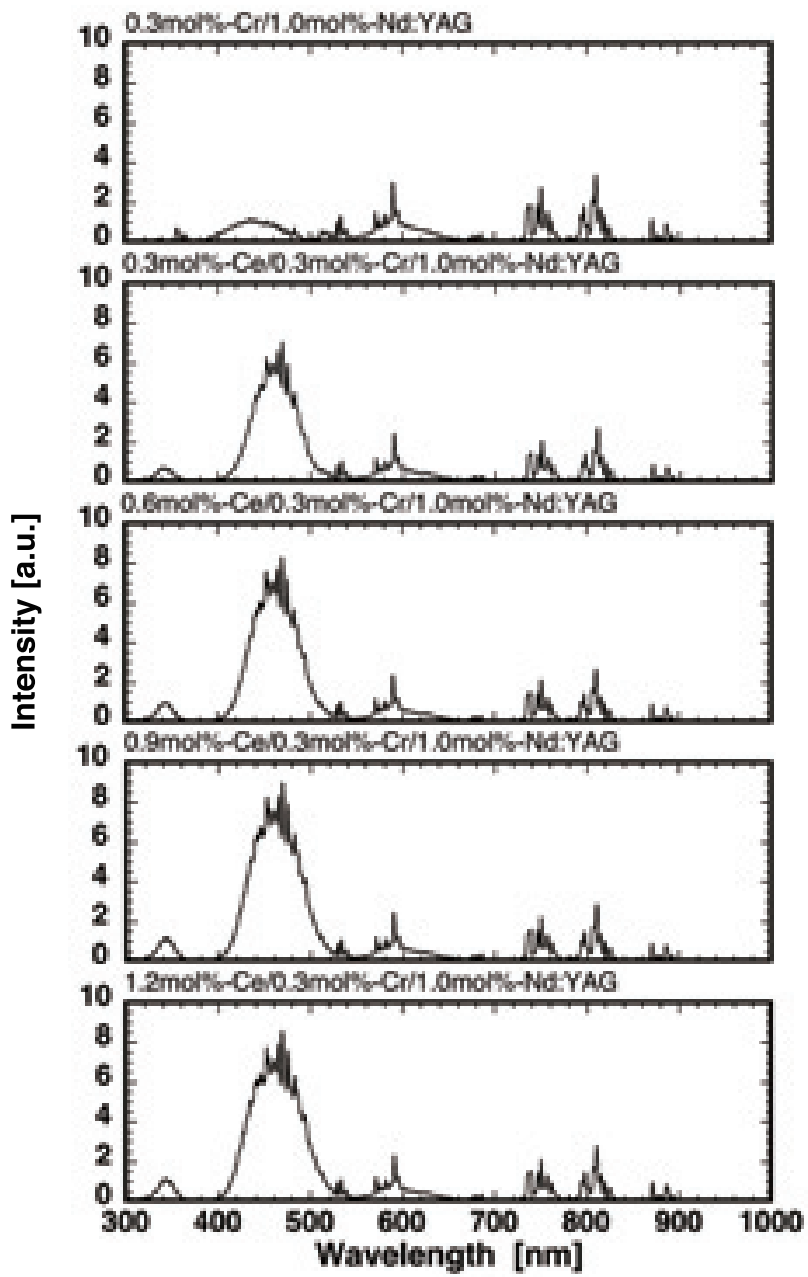

Fig. 7 Excitation spectra of emission at $1064 \mathrm{~nm}$ of $x$ mol\%-Ce/ $0.3 \mathrm{~mol} \%-\mathrm{Cr} / 1.0 \mathrm{~mol} \%$-Nd:YAG. $X=0$, $0.3,0.6,0.9,1.2$

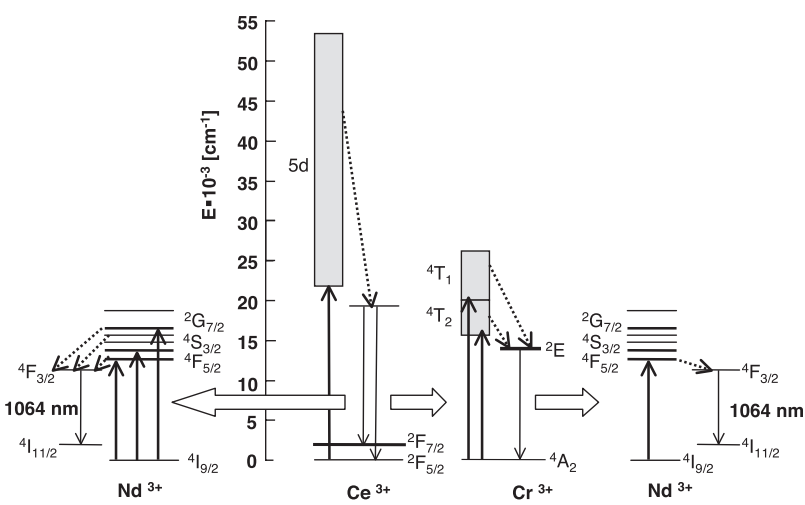

Fig. 8 Energy diagrams of $\mathrm{Ce}^{3+}$ ion, $\mathrm{Cr}^{3+}$ ion, and $\mathrm{Nd}^{3+}$ ion.

$$
N_{N 2}=\frac{k^{\prime} C_{C r} N_{C T}}{1+\left(C_{C r} / C_{C r 0}^{*}\right)^{2}}
$$

$N_{\mathrm{N} 2}$ は $\mathrm{Nd}^{3+}$ の蛍光上準位の数密度, $N_{\mathrm{CT}}$ は $\mathrm{Cr}^{3+}$ の各準位数 密度の総数, $C_{\mathrm{Cr}}$ は $\mathrm{Cr}^{3+}$ 濃度, $C_{\mathrm{C} \mathrm{r} 0}^{*}$ は $\mathrm{Cr}^{3+}$ による濃度消光 パラメータであり, 寿命が $\mathrm{Cr}^{3+}$ 濃度が $0 \mathrm{~mol} \%$ の時の半分 になる $\mathrm{Cr}^{3+}$ 濃度に相当する。 $k^{\prime}$ は各準位間で遷移する割 合を示す係数である。この関係式は, $\mathrm{Ce}^{3+}$ 濃度に対して

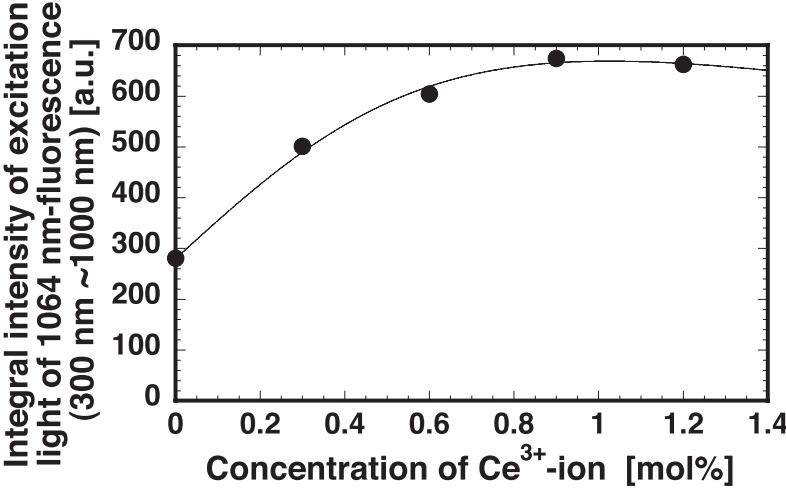

Fig. 9 Dependence of integral area of the excitation spectrum $(300 \mathrm{~nm} \sim 1000 \mathrm{~nm})$ of $x \mathrm{~mol} \%-\mathrm{Ce} /$ $0.3 \mathrm{~mol} \%-\mathrm{Cr} / 1.0 \mathrm{~mol} \%-\mathrm{Nd}$ : YAG on the concentration of $\mathrm{Ce}^{3+}$ ion.

も同様である，蛍光下準位の数密度，遷移の割合を一定 とすると, 蛍光強度 $I$ は $N_{\mathrm{N} 2}$ に比例するので, 以下のよう に書き表せる。

$$
I=a_{(\mathrm{CrNd})}+\frac{a C}{1+\left(C / C_{0}\right)^{2}}
$$

ここで，CはC $\mathrm{Ce}^{3+}$ 濃度， $a$ は係数である， $\mathrm{Ce}^{3+}$ 濃度が $0 \mathrm{~mol} \%$ の場合, Iは $\mathrm{Cr} / \mathrm{Nd}: \mathrm{YAG}$ 蛍光強度 (定数) であるため, $a_{(\mathrm{CrNd})}$ を加えた， $C_{\mathrm{o}}$ は濃度消光パラメータで, Fig. 9を式 (2)でフィッティングした結果， $1.03 \mathrm{~mol} \%$ となった。 こ の值は, Fig. 10に示したCe:YAGにおける $\mathrm{Ce}^{3+} の$ 蛍光寿命 が初期值の半分になる濃度と一致した。

$\mathrm{Ce} / \mathrm{Cr} / \mathrm{Nd}: \mathrm{YAG}$ 中での $1064 \mathrm{~nm}$ 発光の $\mathrm{Nd}^{3+}$ イオンの実効 的蛍光寿命を測定した。 $\mathrm{Nd}^{3+}$ イオンの実効的蛍光寿命の $\mathrm{Ce}^{3+}$ 濃度依存をFig. 11に示す。1.0 mol\%-Nd:YAG中の $\mathrm{Nd}^{3+}$ の蛍光寿命 $(\boldsymbol{\Delta})$ は約 $250 \mu \mathrm{sec}$ であるが, $\mathrm{Cr}^{3+}$ の寿命 が約 $2 \mathrm{msec}$ と長いため, $0.3 \mathrm{~mol} \%-\mathrm{Cr} / 1.0 \mathrm{~mol} \%-\mathrm{Nd}: \mathrm{YAG}$ 中では $\mathrm{Nd}^{3+}$ の実効的蛍光寿命は440 nm励起 ( $)$ で約 420 usecに延びて観測された うに $\mathrm{Ce}^{3+}$ の寿命は非常に短く約60 nsec程度であるが, $\mathrm{Ce}^{3+} 0.3 \mathrm{~mol} \%-\mathrm{Cr} / 1.0 \mathrm{~mol} \%-\mathrm{Nd}: \mathrm{YAG}$ に添加し470 nmで励 起した場合 $(\mathbf{O}), \mathrm{Cr}^{3+}$ の延命効果はほとんど見られず $\mathrm{Nd}^{3+}$ イオンの実効的蛍光寿命は添加する $\mathrm{Ce}^{3+}$ 濃度によら

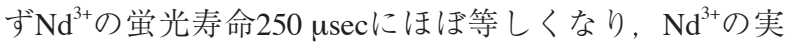

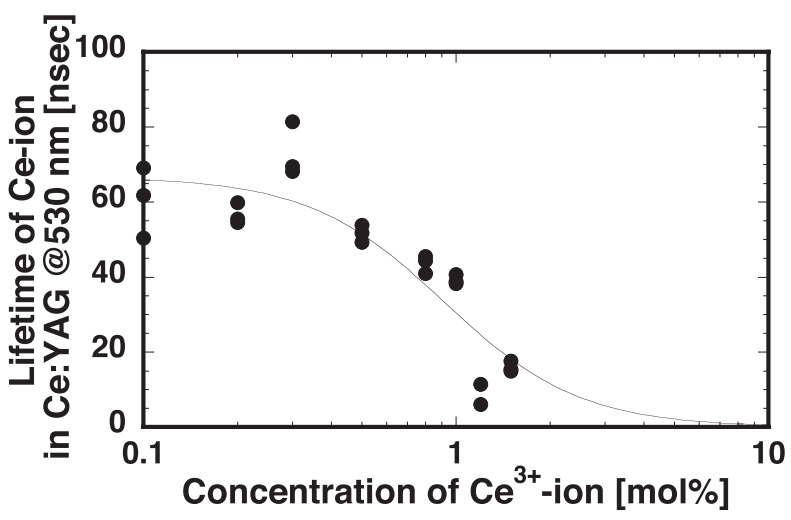

Fig. 10 Dependence of $\mathrm{Ce}^{3+}$ ion-lifetime at $530 \mathrm{~nm}$ in Ce: YAG. 


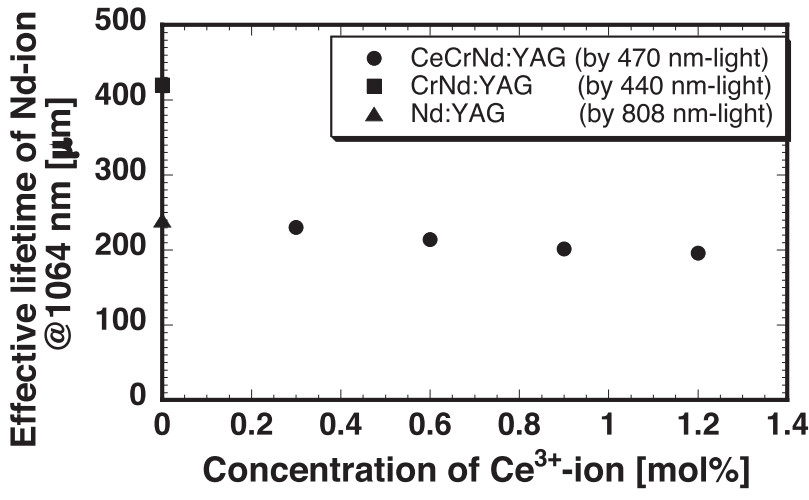

Fig. 11 Dependence of effective $\mathrm{Nd}^{3+}$ ion-lifetime at 1064 $\mathrm{nm}$ on the concentration of $\mathrm{Ce}^{3+}$ ion in $0.3 \mathrm{~mol} \%$ $\mathrm{Cr} / 1.0 \mathrm{~mol} \%-\mathrm{Nd}$ :YAG powder excited by $470 \mathrm{~nm}$-light $(\mathbf{)})$ and $440 \mathrm{~nm}$-light $(\square) . \mathrm{Nd}^{3+}$ ion-lifetime in Nd:YAG at $1064 \mathrm{~nm}$ excited by 808 nm-light $(\boldsymbol{\Delta})$.

効的蛍光寿命は励起効率が最大になる $\mathrm{Ce}^{3+}$ 添加量 0.9

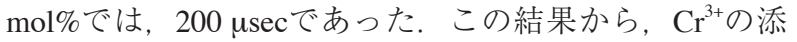
加濃度が $0.3 \mathrm{~mol} \%$ では, $\mathrm{Nd}^{3+}$ イオンへのエネルギー遷移 は $\mathrm{Cr}^{3+}$ イオンを介することなく $\mathrm{Ce}^{3+} \rightarrow \mathrm{Nd}^{3+}$ で起こってい ると考えられる。

\section{4. まとめ}

$\mathrm{Cr} / \mathrm{Nd}$ :YAGに第三の発光元素を添加し太陽光による励 起効率をさらに上げるため, $\mathrm{Ti}^{3+}, \mathrm{Co}^{2+}, \mathrm{Ce}^{3+}, \mathrm{Eu}^{3+}$, $\mathrm{Pr}^{3+}, \mathrm{V}^{3+}$ の6元素をそれぞれYAGにドープしたセラミッ ク粉末をSol-gel法で作製し, 吸収スペクトル, 蛍光特性 を評価した。その結果, $\mathrm{Ce}^{3+}$ が増感剤として有効である ことが分かった. $\mathrm{Ce} / \mathrm{Cr} / \mathrm{Nd}: \mathrm{YAG}$ 蛍光スペクトルは, $\mathrm{Nd}: \mathrm{YAG}$ ものと変わりがなかった. $1064 \mathrm{~nm}$ 発光の励 起スペクトルは, $\mathrm{Cr} / \mathrm{Nd}: \mathrm{YAG}$ スペクトルと比較する と，340 nmにブロードなピークが増え， Cr/ Nd:YAGでは $440 \mathrm{~nm}$ であったピークが470 nmにシフトし, 強度が増 加した。 これらの結果から $\mathrm{Ce}^{3+}$ イオンが $\mathrm{Nd}^{3+}$ イオンへの エネルギー遷移に関与していることがわかった。

励起効率を評価するため, $300 \mathrm{~nm}$ から $1000 \mathrm{~nm}$ の全励 起スペクトルが励起に寄与するものとし, $300 \mathrm{~nm}$ $1000 \mathrm{~nm}$ の励起スペクトル面積のCe $\mathrm{C}^{3+}$ 濃度依存性を調べ た。 励起スペクトル面積が最大になる $\mathrm{Ce}^{3+}$ 濃度は, 高品 質セラミックを安定供給でき，優れた蛍光特性を示す $0.3 \mathrm{~mol} \%-\mathrm{Cr} / 1.0 \mathrm{~mol} \%-\mathrm{Nd}: Y A G に$ 対して0.9 mol\%で, $\mathrm{Ce}^{3+}$ を添加しない場合の約2.4倍であった。

$1064 \mathrm{~nm}$ にける $\mathrm{Nd}^{3+}$ の実効的蛍光寿命は, $\mathrm{Cr} / \mathrm{Nd}$ : YAGの場合, 最長で約 $420 \mu \mathrm{sec}$ あたが, 上記濃度での $\mathrm{Cr} / \mathrm{Nd} / \mathrm{Ce}: \mathrm{YAG}$ 中ではNd:YAG中でのNd ${ }^{3+} の$ 蛍光寿命と同 等の約 $200 \mu \mathrm{sec}$ となった。レーザー動作には問題がない 範囲内での変化である。また, この結果から $\mathrm{Cr}^{3+}$ の添加 濃度が 0.3 mol\%では，エネルギー遷移は，ほとんどが
$\mathrm{Cr}^{3+}$ イオンを介さない $\mathrm{Ce}^{3+} \rightarrow \mathrm{Nd}^{3+}$ であると考えられる

以上より $\mathrm{Ce} / \mathrm{Cr} / \mathrm{Nd}$ : $\mathrm{YAG}$ は太陽光励起レーザーにおい

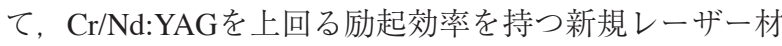
料として期待できることがわかった。また， $\mathrm{Ce}^{3+}$ イオン には紫外線照射による色中心発生を防止する働きがあ り，そのような付加価值も期待できる.

謝 辞

本研究は, 関西電力受託研究「太陽光励起レーザーに よる高効率光電变換システムの要素技術開発に関する研 究」の中で実施された。ここに謝意を表します。

\section{参考文献}

1) Z. J. Kiss and R. C. Duncan: Appl. Phys. Lett. 5 (1964) 200.

2) M. J. Taylor: Pro. Phys. Soc. 90 (1967) 48.

3) D. Pruss, G. Huber, A. Beimowski, V. V. Laptev, I. A. Shcherbakov, and Y. V. Zharikov: Appl. Phys. B 28 (1982) 355.

4) E. Reed, I. Coherent, and C. A. Palo Alto: IEEE J. Quantum Electron. 21 (1985) 1625

5) J. A. Caird, M. D. Shinn, T. A. Kirchoff, L. K. Smith, and R. E. Wilder: Appl. Opt. 25 (1986) 4294.

6) I. A. Shcherbakov: IEEE J. Quantum Electron. 24 (1988) 979.

7) P. Hong, X. X. Zhang, C. W. Struck, and B. Di Bartolo: J. Appl. Phys. 78 (1995) 4659.

8) A. Ikesue, K. Kamate, and K. Yoshida: J. Am. Ceram. Soc. 78 (1995) 2545.

9) Jiang Li, Yusong Wu, Yubai Pan, Wenbin Liu, Yong Zhu, and Jingkun Guo: J. Ceram. Soc. Jpn. 116 (2008) 572.

10) H. Yagi, K. Takaichi, K. Ueda, T. Yanagitani, and A. A. Kaminskii: Opt. Mater. 29 (2006) 392.

11) H. Yagi, T. Yanagitani, H. Yoshida, M. Nakatsuka, and K. Ueda: Jpn. J. Appl. Phys. 45 (2006) 133.

12) H. Yagi, K. Takaichi, K. Wada, K. Ueda, and T. Yanagitani: Jpn. J. Appl. Phys. Part 245 (2006) 207.

13) 佐伯拓, 今崎一夫, 本越伸二, 内田成明, 藤田尚徳, 中塚正大, 井澤靖和, 山中千代衛：レーザー研究 34 (2006) 374.

14) T. Saiki, K. Imasaki, S. Motokoshi, C. Yamanaka, H. Fujita, M. Nakatsuka, and Y. Izawa: Opt. Commun. 268 (2006) 155.

15) T. Saiki, S. Motokoshi, K. Imasaki, H. Fujita, M. Nakatsuka, and C. Yamanaka, Jpn. J. Appl. Phys. 46 (2007) 156.

16) T. Saiki, S. Motokoshi, K. Imasaki, K. Fujioka, H. Fujita, M. Nakatsuka, Y. Izawa, and C. Yamanaka: Jpn. J. Appl. Phys. 47 (2008) 7896.

17) T. Saiki, K. Funahashi, S. Motokoshi, K. Imasaki, K. Fujioka, H. Fujita, M. Nakatsuka, and C. Yamanaka: Opt. Commun. 282 (2009) 614.

18) T. Saiki, S. Motokoshi, K. Imasaki, M. Nakatsuka, C. Yamanaka, K. Fujioka, and H. Fujita: Opt. Commun. 282 (2009) 936.

19) T. Saiki, S. Motokoshi, K. Imasaki, K. Fujioka, H. Yoshida, H. Fujita, M. Nakatsuka, and C. Yamanaka: Opt. Commun. 280 (2009) 1358

20) T. Saiki, S. Motokoshi, K. Imasaki, H. Fujita, M. Nakatsuka, and C. Yamanaka: Jpn. J. Appl. Phys. 46 (2007) 156.

21）藤岡加奈, 佐伯拓, 本越伸二, 藤本靖, 中塚正大：レー ザー研究 35 (2007) 393.

22) K. Fujioka, T. Saiki, S. Motokoshi, Y. Fujimoto, H. Fujita, and M. Nakastuka: Ceram. Int. 35 (2009) 2393.

23) International Center for Diffraction Data (ICDD) card \#33-0040.

24) R. D. Shannon: Acta Cryst. A32 (1976) 751.

25) K. Fujioka, T. Saiki, S. Motokoshi, Y Fujimoto, H. Fujita, and M. Nakastuka: J. Lumin. 130 (2010) 455. 